DOI: $10.1515 / \mathrm{rpp}-2016-0021$

PhD in Pedagogical Sciences, Lecturer, MARYNA ZEMBYTSKA

Khmelnytskyi National University, Ukraine

Address: 11 Instytutska St., Khmelnytskyi, 25016, Ukraine

E-mail: zembitska@i.ua

\title{
MENTORING AS THE CORE ELEMENT \\ OF NEW TEACHER INDUCTION IN THE USA: POLICIES AND PRACTICES
}

\begin{abstract}
The paper focuses on mentoring as the key strategy of novice teacher induction in the USA. The study reviews current mentoring/induction policies and trends in the U.S. system of in-service teacher training and support. The findings suggest that the conceptual framework, standards and practices of new teacher mentoring in the United States conform to the dynamic trends in education and organizational management. The conceptual modification of teacher mentoring manifests itself in the development of comprehensive and sustained formal induction programs based on the theories of educational leadership, adult learning, social interaction and collaborative learning. Quality induction programs are context-based and involve multiple stakeholders (schools, school districts, local educational organizations and agencies, partner universities, state departments of education etc). Diverse forms of mentoring (one-to-one, peer, group, reciprocal, online and needs-driven mentoring, etc.) are extensively combined with other induction components offered to beginning teachers and mentors during the whole induction period. The induction components include: summer courses, orientation sessions, workshops, seminars, webinars, conferences, interviews, informal meetings and celebrations, district-based mentor training programs etc. The quantitative data obtained through the analysis of the U.S. national surveys and research reports provides ground for highlighting those mentoring and induction programs which have significantly decreased turnover rates among new teachers, contributed to their professional development and improved academic achievement in public schools by providing students with quality instruction.
\end{abstract}

Key words: mentoring, beginning/novice teacher, mentor, protégé/mentee, new teacher induction, induction program, in-service training, professional development.

\section{INTRODUCTION}

Since the quality of instruction has been identified as the most important schoolbased factor effecting student achievement (Rivkin, Hanushek, 2007; Wayne \& Young, 2003; Wong, 2004), researchers urge that every effort should be made to supply the schools with quality teaching force, to address teachers' needs and facilitate their professional development. Numerous surveys (Veenman, 1985; Charnock \& Kiley, 1995; Hudson, 2012) demonstrate that the vast majority of teachers remember their first in-service years as a stressful period of trial and error while teaching and learning how to teach. It is fairly doubtful that having a fieldwork experience limited to 10 to 16 weeks of student teaching, a newly qualified teacher should immediately become a professional and perform at the level of a veteran teacher. For seamless transition through the critical phases of the first year (anticipation I, survival, disillusionment, rejuvenation, reflection and anticipation II) (E. Moir, 1985) and developmental stages (survival, consolidation, renewal, maturity) (Katz, 1972), novices should be provided with an adequate administrative and collegial support, as well as 
opportunities of embedded professional development. Since novice teachers rated mentor's support the most important factor during the induction phase (along with administrator's support, collaboration with colleagues, professional learning communities, self-developed professional growth plan and self-reflection opportunities) (Behrstock-Sherratt et al., 2014), an investigation of effective mentoring policies and practices is needed.

\section{THE AIM OF THE STUDY}

The aim of the study is to analyze the features, policies and trends of teacher mentoring as part of induction support in the USA.

\section{THEORETICAL FRAMEWORK AND RESEARCH METHODS}

For the past three decades, numerous studies describing the genesis, meaning, conceptual framework and benefits of mentoring have been published. In recent studies of American researchers (B. Adams, T. Bey, L. Darling-Hammond, C. Evertson, S. Fletcher, J. Fluckiger, C. Galvez-Hjornevik, T. Ganser, L. Huling-Austin, R. Ingersoll, M. Jacobi, J. Little, S. Feiman-Nemser, S. Merriam, E. Moir, S. Odell, H. Portner, M. Smithey, M. Strong, L. Tillman, H. Wong, et al.) mentoring expands beyond the formerly accepted definition of mentoring as a method of knowledge and skill transfer to understanding mentoring as part of lifelong learning and professional development, key support strategy and mutually beneficial developmental partnership. Some theoretical and practical aspects of mentoring as an interpersonal exchange between an experienced teacher and a beginning teacher ( $0-3$ years) characterized by guidance, advice, feedback and support are revealed in the dissertations of Ukrainian researchers Y. Belmaz, Y. Bondaruk, T. Chuvakova, T. Koshmanova, M. Nahach, R. Roman, O. Sadovets, et al. The findings of the current study were obtained using such research methods as comparative analysis, content analysis, systematization and theoretical summarization.

\section{RESULTS}

The review of related research shows that the use of mentoring as the method of one-to-one knowledge and skill transfer is traced back to the XIII century, when a beginning teacher (apprentice) mirrored an experienced teacher by copying his/her style, speech and technique, thus gaining practical experience without any theoretical background. When compared with the classification of Hargreaves and Fullan (2000), this period corresponds to the pre-professional age of mentoring which coincided with beginning of mass education and lasted until the early post-war years. Mentoring of the pre-professional age did not address new teachers' needs. In the $19^{\text {th }}$ century, the model of one-way mentor-protégé knowledge transfer was prevailing. According to Hargreaves and Fullan (2000), the age of the autonomous professional came out of the social revolutions of the 1960s. Teachers worked in isolation as professionally autonomous, having limited access to shared expertise and collaborative innovative practices. Mentoring was available for new teachers only. The age of the collegial professional arrived when the growing complexity of teaching became acknowledged. The end of the $20^{\text {th }}$ century, which brought the educational reforms of the 1980 s, became the milestone in the evolution of mentoring in the USA. The scale and number of implemented teacher induction programs have significantly increased since the mid-1980s. A fundamental feature of mentoring in the post-professional age, which began in the $21^{\text {st }}$ century, is the development of teacher communities for learning and sharing the expertise (Hargreaves \& Fullan, 2000). The strategies of collaborative development being predominant in American organizational management, collegial forms of teacher mentoring are consistently gaining popularity: peer mentoring, group mentoring, team mentoring, reciprocal mentoring.

Taking into consideration the historical background of mentoring, the following periods in its evolution can be distinguished: pre-institutional (1960s -1970s) - associated with the beginning of mentoring as targeted practical assistance to beginning teachers, with 
informal one-to-one mentoring being the prevailing model of teacher support; institutional (1980s - 1990s) - implementation and increasing number of formal mentoring programs; implementation of state-level induction programs aimed at increasing teacher quality and retention, with mentoring as their key component; providing mentoring programs with multi-level institutional support; development of policies for its design and implementation; incorporate (early $21^{\text {st }}$ century - current time) - the advance of mentoring characterized by the conceptual modification of mentoring (andragogical model of mentoring), diversification of its functions, approaches, form and methods; participation of multiple stakeholders and tailoring the programs to satisfy their needs; adoption of state-level mentoring standards; providing mentors with incentives and opportunities of ongoing training and support; providing sufficient mentoring/induction program funding; incorporating mentoring into collaborative job-embedded professional development; applying the interdisciplinary approaches to mentoring research.

It becomes evident from the historical background of mentoring and related studies (Hargreaves \& Fullan, 2000; Feiman-Nemser et al., 1999; Wang et al., 2010) that approaches to new teacher mentoring in the USA were socially predetermined at different eras. Currently, the development of mentoring and induction strategies in the USA to a certain extent is associated with the problem of increased teacher turnover (which includes both teacher attrition and internal migration), which is especially urgent with teachers of science, math, foreign languages and special education.

High teacher turnover in American public schools, particularly in low-income and high-minority urban public schools, puts psychosocial function of mentoring at the forefront of induction programs. Enhanced psychosocial support has proved effective with unsupported novices who are more vulnerable than other occupational groups (Ingersoll, 2001; Ingersoll, 2002). According to Hanushek \& Rivkin (2007), teacher turnover rates differ sharply by number of years in teaching profession. New teachers are almost twice as likely as teachers with 11 to 30 years' experience to exit Texas public schools and almost four times as likely to migrate to other districts.

Even though some degree of staff turnover is inevitable and can be beneficial for organizations by preventing stagnation, eliminating low performers and promoting innovation (Ingersoll \& Merrill, 2012), the statistics reveals a devastating shortage of public school teachers: $14 \%$ of first-year teachers leave the profession by the end of the 1 st year, $33 \%$ leave within the first 3 years, and $40 \%$ to $46 \%$ leave within the first 5 years (Ingersoll, 2002). According to NCTAF's calculations, the national cost of teacher turnover is over $\$ 7$ billion annually, which includes costs for training, recruiting and hiring new teachers (Carroll, 2007).

The analysis of research and numerous reports of national educational agencies and organizations (NCES, NCTAF, NEA, NTC, etc.) shows that among all the governmental initiatives to retain effective teachers in American public schools since 1980s up to the present time (financial incentives for teachers, salary increases, standardization reform, alternative teacher certification, flexible licensure schemes, in-service teacher support, etc.), new teacher mentoring and induction have proven to be highly efficient and cost-effective. The calculated return (Villar and Strong, 2007) on investment of an induction program in California after five years is as much as $\$ 1.66$ for every dollar spent. The study of H. K. Wong (2004), as well as numerous studies of other researchers, provides evidence of a significant decrease in teacher attrition - reduced to as little as $2.2 \%-3.9 \%$ after the implementation of Lafourche induction program in Louisiana. Among large-scale mentoring practices which had a positive impact on teacher performance and turnover the following programs should primarily be highlighted: Beginning Teacher Support and Assessment 
(BTSA, California), Beginning Educator Support Team (BEST, Washington), Louisiana FIRST, Alaska statewide mentor project, New Teacher Project (New York), etc.

Teacher mentoring in the U.S. education system usually refers to in-service assistance and support of beginning teachers with $0-3$ years of experience, but it may also imply: a) practical training of pre-service teachers - student teaching; b) counseling and guiding the socialization of teachers who arrived from another state or school district even though they already have some teaching experience; c) supporting teachers who are getting back to work after a long break (more than 3 years) (Zembytska, 2015). As researchers (Wong, 2004; Alliance for Excellent Education, 2004) argue that mentoring alone is not sufficient to significantly reduce beginning teacher turnover and increase the quality of instruction, it is extensively combined with other types of new teacher support which together form an induction program. Mentoring is the core element of any induction program, but positive outcomes are more probable when it is combined with such types of district- and school-based induction support as orientation sessions, workshops, seminars, summer training (summer institute), lectures, debates, formal and informal meetings, surveys, assessments, interviews, etc.

Since U.S. education system is decentralized, the content, duration and funding of induction programs vary greatly among the states and school districts. The intensity of induction support may range from a formal orientation session prior to the start of the school year to multi-faceted, sustained and coherent program with multiple components and extensive professional development opportunities for beginning teachers. Comprehensive induction programs provide diverse instructional support that includes: an assigned on-site mentor (either full-time, working with a several or more novices, or part-time - working with one mentee); supportive communication with the building administrator and district-based administrators; common planning or collaboration time with mentor and other teachers in the field; reduced number of preparations; ongoing assessment (internal and external evaluation of the effectiveness of mentor-mentee cooperation, standards-based evaluation of beginning teacher's performance); participation in an external teacher network.

Most states have adopted either mentoring or induction standards for local school districts (such as Michigan's Teacher Induction and Mentoring Standards, North Carolina Mentor Standards, New York State Mentoring Standards, etc.). Many of them have specified mentor standards and special assessment criteria for mentor development (NTC Continuum of Mentoring Practice, North Carolina Mentoring Continuum, etc.). Some specifications concerning the design and organization of mentoring and induction programs are included in states' Education Code and Professional Development Standards, Professional Teaching Standards, etc.

Although the content of the standards may vary in different states, most of them articulate the vision of programs designed to specifically meet local and state teaching standards, address the teachers' needs and diversity issues. They contain selection criteria, roles and responsibilities of participants and stakeholders (schools, districts, partner universities, local education agencies, professional unions and organizations, etc.), as well as types of support and incentives for both new teachers and mentors. The standards specify the professional development opportunities and articulate the coordination of the induction programs with local professional teacher training programs.

The majority of standards provide an evaluation procedure of teacher induction and mentoring. For example, a beginning teacher under North Carolina Policies on the Beginning Teacher Support Program is observed at least 4 times per year during the first 3 years with a summative evaluation in the end of each year. Meanwhile, other policy papers require that 
formative assessment (evaluation) should be used to guide mentoring and professional development of a beginning teacher. In contrast to summative evaluation, which is sometimes perceived as a violation of the principles of partnership underlying the mentoring relationship, formative assessment does not influence important career-related decisions. Formative assessment can be based on: students' needs assessment, self-reflection (e.g. reflective journals, mentee's $\log$ ), analyzing students' achievement, mentor and peer observations. Pre-observation and post-observation conferences are held by mentors and program coordinators/facilitators to stimulate reflective teaching of novices.

A common requirement is that new teacher induction and mentoring program plans should align with the Professional Teaching Standards adopted in a particular state, content area standards and applicable local school improvement and professional development plans. Within each program, mentees are required to keep an Individual Professional Development Plan through record keeping and accountability. Participating teachers are assessed on the basis of state-adopted academic content standards and students' achievement. Ongoing program assessment is based on the internal and external sources, such as participants, administration, students, program coordinator/facilitator.

It was found that mentors are trained through different types of individual and collaborative activities: orientation sessions, presentation of available instructional materials and resources for self-education, coaching, training, reflective workshops, teaching seminars, conferences, communication with program coordinator and school administrator, participation in discussion panels or problem solving groups, mentor support groups and mentor communities. Comprehensive mentoring programs in the United States include previous and ongoing training of mentors in adult learning theory, acmeology, psychology of interpersonal relationships, educational management, educational leadership, pedagogy and teaching methods, coaching and counseling, classroom observation strategies, instructional resources and support networks, latest achievements in pedagogy and curriculum and research projects. Mentors are trained to apply adult learning concepts to mentoring, which includes: allowing time to listen to the mentee's ideas and rely on their day-to-day experience; making meaningful suggestions; working with the mentee to identify possible areas of incompetence or uncertainty; encouraging the beginning teacher's reflective skills. Currently, mentor training prior to the program is required in 31 states. In 15 states it is followed by on-going professional development for mentors (Goldrick et al., 2012).

Mentor selection and matching in the reviewed states is carried out by principals, site coordinators, program facilitators and lead mentors. Basic mentor selection criteria include: interpersonal skills, instructional effectiveness, leadership, work experience, contentarea and grade-level expertise similar to the mentee's assignment (Alliance for Excellent Education, 2004; Goldrick, Osta, Barlin, \& Burn, 2012; Ingersoll \& Strong, 2011). American researchers suggest that the optimal mentor/mentee age difference is about $8-15$ years, but taking into account high teacher attrition in U.S. public schools, administrators often invite retired teachers who have the enthusiasm and expertise to renew their contracts and work as new teacher mentors. Since serving as a mentor is voluntary, most school districts offer some incentives to encourage mentors, such as: a) reduced workload (released time for frequent meetings with their protégés); b) stipends or salary supplements; c) advanced career opportunities; d) presents, certificates, awards, end-of-year and graduation ceremonies in recognition of mentor's contribution.

The results of surveys (Rowley, 1999; NCIEC, 2007) conducted among newly qualified teachers and their mentors show that respondents complain about having to keep a detailed record of mentoring process (by writing in a Mentor Log, Online Mentor Log, 
Reflective Journal, Individual Professional Development Plan, Mentor/Mentee Activity Sheet, Self-Assessment Form, Teacher Self Evaluation, Self-Reflective Portfolio, annual reports, formative and summative evaluation forms, etc.) and prefer interactive districtbased workshops to traditional lectures and seminars.

\section{CONCLUSIONS}

Our results add to the extant body of research on mentoring by highlighting the policies and practices of new teacher mentoring and induction in the United States. The findings show that most states have adopted some state-level policies which set general requirements and rules of mentoring and induction support to be met by local school districts. Acknowledging the importance and growing complexity of mentoring, many programs offer some incentives to encourage mentors and provide an ongoing training designed specifically to help mentors assume their new roles: workshops addressing leadership styles, time management and carrying out research projects; experiential orientation to techniques of observation, guidance, coaching and adult learning strategies, leadership styles and time management, etc.

Investigation of different aspects and effects of in-service training, development and support strategies could contribute to the solution of the problems related to the teaching profession - high teacher turnover, low performance, stagnation and emotional burnout, etc. Additional inquiry is needed to examine gender issues in mentoring relationship, adult learning techniques in mentoring and assessment of mentor-mentee interaction. With the growing number of alternate route teachers beginning teachers affecting K-12 education, further research on enhanced mentoring practices for alternate route teachers would contribute to the development mentoring not only as a support mechanism but also as a powerful strategy of personalized long-term training within the induction program to make sure that a teacher candidate is qualified to teach, meets the competency standards and licensure requirements. Research would also benefit from analyzing ways to tailor mentoring and induction strategies to the needs of new teachers in ethnically diverse communities.

\section{REFERENCES}

1. Alliance for Excellent Education. (2004). Tapping the potential. Retaining and Developing High-Quality New Teachers. Washington, D.C. : Alliance for Excellent Education, $22 \mathrm{p}$.

2. Behrstock-Sherratt, E., Bassett, K., Olson, D., Jacques, C. (2014). From Good to Great. Exemplary Teachers Share Perspectives on Increasing Teacher Effectiveness Across the Career Continuum. Retrieved 30.05.2016 from : http://www.gtlcenter.org/sites/default/ files/Good_to_Great_Report.pdf.

3. Carroll, T. G. (2007). Policy Brief. The High Cost of Teacher Turnover. Prepared for the National Commission on Teaching and America's Future, Washington, D.C., 1 p.

4. Charnock B., Kiley, M. (1995). Concerns and Preferred Assistance Strategies of Beginning Middle and High School Teachers. San Francisco, CA, 1 p.

5. Feiman-Nemser, S., Schwille, S., Carver, C., \& Yusko, B. (1999). A Conceptual Review of Literature on New Teacher Induction. College Park, Maryland : National Partnership for Excellence and Accountability in Teaching, $47 \mathrm{p}$.

6. Goldrick, L., Osta, D., Barlin, D., \& Burn, J. (2012). Review of State Policies on Teacher Induction. Retrieved 30.05.2016 from : www.newteachercenter.org. 
7. Hanushek, E. A., \& Rivkin, S. (2007). Pay, Working Conditions and Teaching Quality. The Future of Children, Volume 17 (1), pp. 69-86.

8. Hargreaves, A., Fullan, M. (2000). Mentoring in the New Millennium. Retrieved 28.05.2016 from : http://professionallyspeaking.oct.ca/december_1999/mentoring.htm.

9. Hudson, P. (2012). How Can Schools Support Beginning Teacher? A Call for Timely Induction and Mentoring for Effective Teaching. Australian Journal of Teacher Education, Volume 37, Issue 7, pp. 71-84.

10. Ingersoll, R. (2001). Teacher Turnover, Teacher Shortages and the Organization of Schools. American Educational Research Journal, Volume 38, Issue 3, pp. 499-534.

11. Ingersoll, R. M. (2002). The Teacher Shortage: A Case of Wrong Diagnosis and Wrong Prescription. NASSP Bulletin, Volume 86, No 631, pp. 16-31.

12. Ingersoll, R., Merrill, E. (2012). Seven Trends: The Transformation of the Teaching Force. CPRE Working Paper. Retrieved 29.05.2016 from : http://repository. upenn.edu/cgi/viewcontent.cgi?article $=1261 \&$ context $=$ gse pubs.

13. Katz, L. G. (1972). Developmental Stages of Preschool Teachers. Elementary School Journal, Volume 73 (1), pp. 50-54.

14. National Consortium of Interpreter Education Centers (NCIEC). (2007). Identifying Effective Practices: Survey Results of Mentors. Retrieved 29.05.2016 from : http://www.northeastern.edu/bostonmodernism/wp-content/uploads/Mentor-Survey-Results.pdf.

15. Rowley, J. B. (1999). The Good Mentor. Supporting New Teachers, Volume 56, No 8, pp. 20-22.

16. Veenman, S. (1985). Perceived Problems of Beginning Teachers. Review of Educational Research, No 54 (2), pp. 143-178.

17. Villar, A., Strong, M. (2007). Is Mentoring Worth the Money? A Benefit-Cost Analysis and Five-Year Rate of Return of a Comprehensive Mentoring Program for Beginning Teachers. Retrieved 30.05.2016 from : https://www1.maine.gov/education/teacherinduction/ forms/Mentoring\%20Article.pdf.

18. Wang, J., Odell, S. J., Clift, R. T. (2010). Past, Present, and Future Research on Teacher Induction: An Anthology for Researchers, Policy Makers, and Practitioners. R\&L Education, $268 \mathrm{p}$.

19. Wayne, A. J., Youngs, P. (2003). Teacher Characteristics and Student Achievement Gains: A Review. Review of Educational Research, Volume 73, No 1, pp. 89-122.

20. Wong, H. K. (2004). Induction Programs that Keep New Teachers Teaching and Improving. NASSP Bulletin, Volume 88, No 638, pp. 41-58. 